\title{
Glacial morphology and depositional sequences of the Antarctic continental shelf
}

\author{
Uri S. ten Brink \\ Christopher Schneider \\ U.S. Geological Survey, Woods Hole, Massachusetts 02543
}

\begin{abstract}
We propose a simple model for the unusual depositional sequences and morphology of the Antarctic continental shelf. Our model considers the regional stratal geometry and the reversed morphology of the Antarctic continental shelf to be principally the results of time-integrated effects of glacial erosion and sedimentation related to the location of the ice grounding line. The model offers several guidelines for stratigraphic interpretation of the Antarctic shelf and a Northern Hemisphere shelf, both of which were subject to many glacial advances and retreats.
\end{abstract}

\section{INTRODUCTION}

Modern continental shelves are typically covered by relatively shallow waters $(<200 \mathrm{~m})$ and deepen gradually from the coast to the shelf edge. The stratal geometry of shelf deposits is determined largely by the relative rates of sediment supply, tectonic subsidence, and eustatic changes. The morphology of the Antarctic shelf (Fig. 1) is different: it gradually shallows from the inner shelf, where it sometimes reaches $0.8-1.3$ $\mathrm{km}$ depth (Fig. 1A), to the shelf edge, where it is $200-400 \mathrm{~m}$ deep. The stratal geometry of the Cenozoic Antarctic shelf resembles that of highstand and shelf-margin-wedge systems tracts (Fig. 1B; Bartek et al., 1991). Lowstand and transgressive systems tracts have not been identified (Bartek et al., 1991). The depositional sequences are characterized by aggradation of thin, continuous layers tens of kilometres long and by rapid seaward progradation of proglacial glaciomarine sediments (Anderson, 1991). They are characterized further by toplap and offlap relations on the outer shelf (Fig. 1B), where only a few unconformities truncate steeply dipping prograded sequences (Fig. 1A).
The reversed and unusually deep shelf morphology is a general feature (Johnson et al., 1982), despite the varied tectonic histories of different segments of the Antarctic margin (ten Brink and Cooper, 1992). For example, the breakup of East Antarctica from India in Prydz Bay (Fig. 1A) occurred at $128 \mathrm{Ma}$; therefore, residual thermal subsidence from rifting since the start of glaciation at $\sim 40 \mathrm{Ma}$ has been small. The Pacific margin of the Antarctic Peninsula (Fig. 1B) was, on the other hand, subject to collision and subduction until 3-4 Ma (Larter and Barker, 1991). Noting the similar shelf mor-

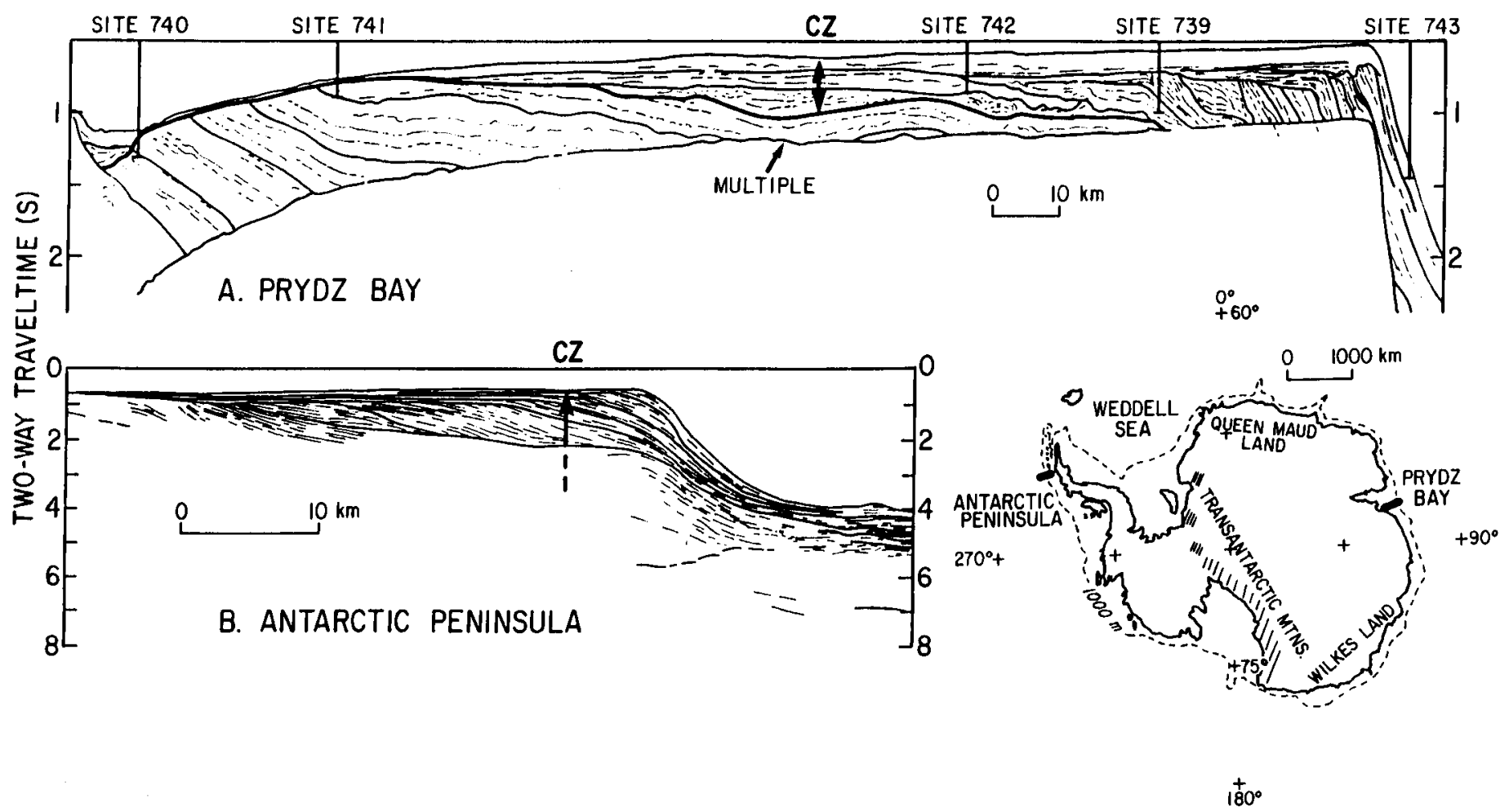

Figure 1. Line drawings of seismic lines across Antarctic shelf at Prydz Bay (A), and Antarctic Peninsula (B) (Cooper et al., 1991; Larter and Barker, 1991). CZ-Cenozoic glacial sedimentary section. Sites 739-743-Ocean Drilling Program drill sites during Leg 119. 
phology, ten Brink and Cooper (1992) investigated several factors that were likely to influence the bathymetry of the shelf. Their models show that the morphology can be produced almost entirely by the sum of outer-shelf and slope sediment loading and inner-shelf unloading associated with glaciation, whereas ice loading, isostatic response of the lithosphere, thermal and tectonic subsidence of the margin, and sealevel changes had much less influence on the morphology.

The construction of process-based models relating past Antarctic ice-sheet fluctuations to the observed morphology and stratigraphy is difficult, because a variety of glacial and glaciomarine processes probably operated through time and space. These processes depend on past climate (temperate vs. polar ice sheet) and location (mountain glacier, ice shelf, ice streams, etc.) (e.g., Dowdeswell and Scourse, 1990; Anderson and Ashley, 1991), for which there are few constraints. Aqueous and biogenic processes ahead of the fluctuating grounding line further complicate such models (Domack et al., 1991). Our approach is to construct stochastic models that simulate the development of the broad-scale features of the continental shelf and compare them to observations. The simplifying assumption of the model is that the morphology and the regional stratal geometry of glaciated shelves are principally the results of timeintegrated effects of glacial erosion and sedimentation and the location of the ice grounding line. Although this approach is incomplete, it provides insight into the relation between glacial fluctuations and shelf morphology and stratigraphy.

\section{MODELS}

In the models we divide the width of the continental shelf, slope, and rise into $\mathrm{N}$ positions and assume that the glacial grounding line reaches one of these positions during a particular cycle of ice advance or retreat (Fig. 2). If the position is seaward of the shelf edge, the grounding line remains at the shelf edge, because increasing water depth constrains its further advance. Because the positions of the grounding line through time are unknown, we ran two sets of experiments-one where the positions are determined by a computer-generated uniform random number series, and one with global ice-volume-dependent positions (via the $\delta^{18} \mathrm{O}$ series). Here we discuss only the random schemes in which the ice grounding line is expected to occupy all available positions, $\mathrm{N}$, after $\mathrm{N} \ln \mathrm{N}$ cycles of glacial advance and retreat (Feller, 1968). In our models we use 111 cycles to ensure that
Figure 2. One cycle of glacial position in model. Patterns of deposition on shelf ahead of grounding line and erosion behind grounding line are similar for all cycles and are only functions of distance from grounding line. When deposition extends to slope, all remaining sediments fill first slope position. When this position is filled, it becomes part of

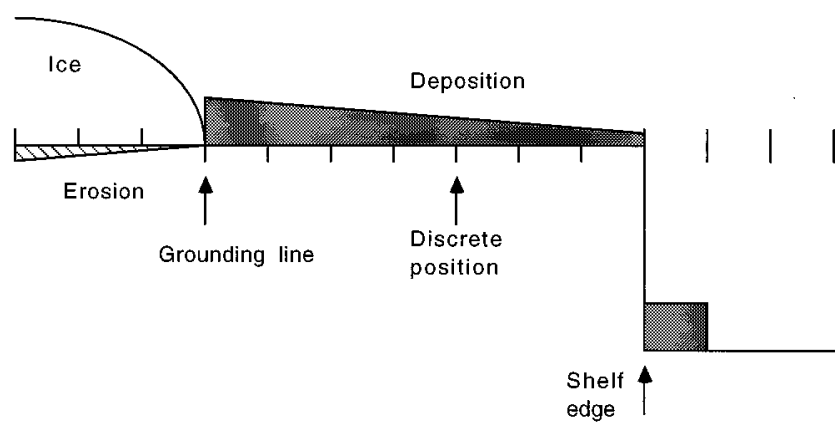
shelf, and next position starts being filled. Note that model is nondimensional, having positions along shelf serve as distance axis and units of deposition or erosion as vertical axis. However, incorporating flexural isostasy and thermal subsidence requires physical dimensions. Each position is equated with $10 \mathrm{~km}$ (i.e., total shelf width of $200-270 \mathrm{~km}$ ) and each sediment unit is equated with $5 \mathrm{~m}$ (based upon thickness of Quaternary sediments recovered in Prydz Bay; Barron, Larsen, et al., 1989).
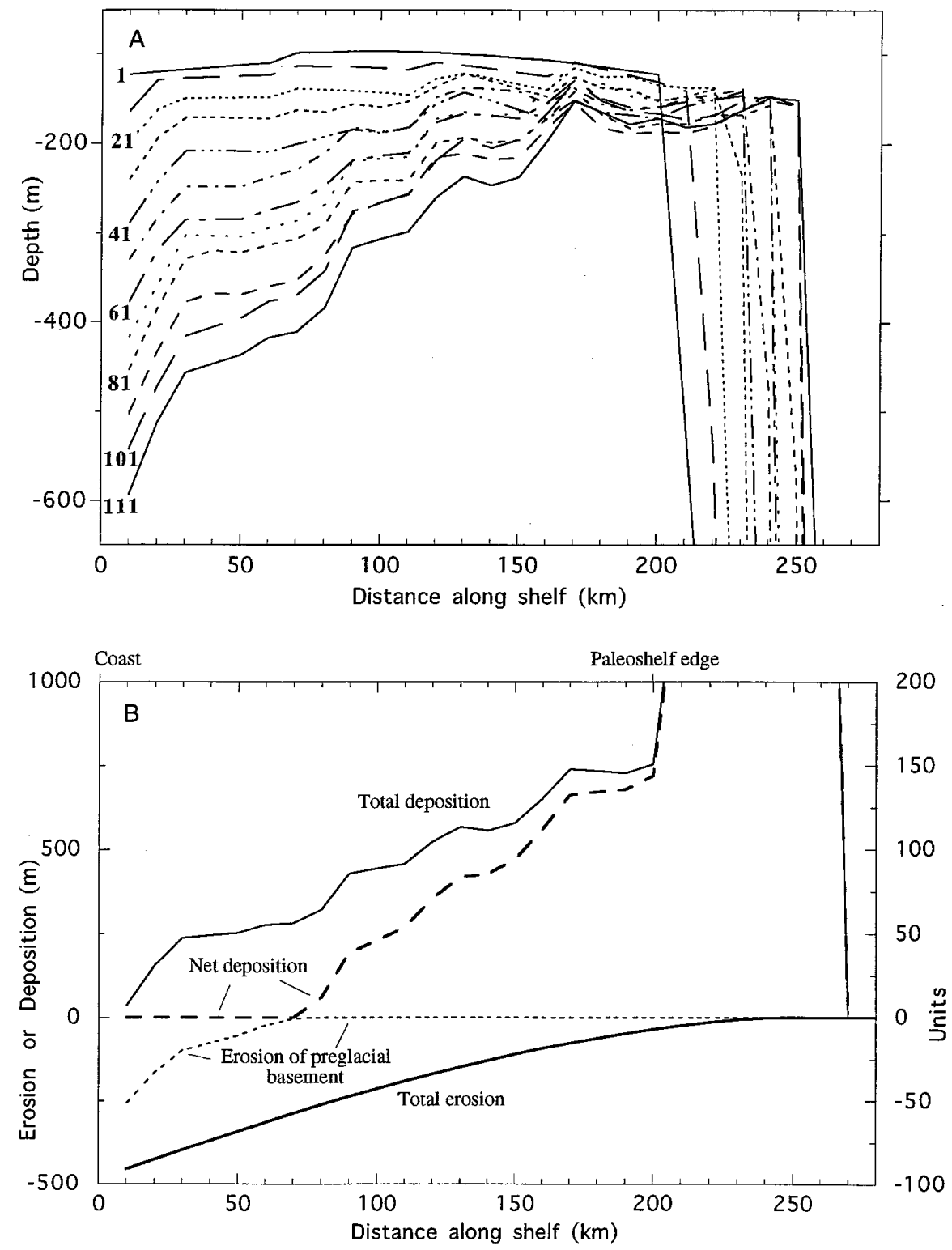

Figure 3. A: Incremental sea-floor morphology every 10 cycles for model in Figure 4A. Note that inner-shelf trough and reverse morphology develop only after $\sim 20$ cycles of glacial advance and retreat. B: Sums of total erosion, total deposition, net deposition (after glacial erosion), and erosion into preglacial basement, as function of position across shelf from model in Figure 4A. Difference between total and net deposition indicates degree of sediment reworking. Curves of erosion of preglacial sediments plus net deposition constitute bathymetry due only to sediment erosion and deposition. 


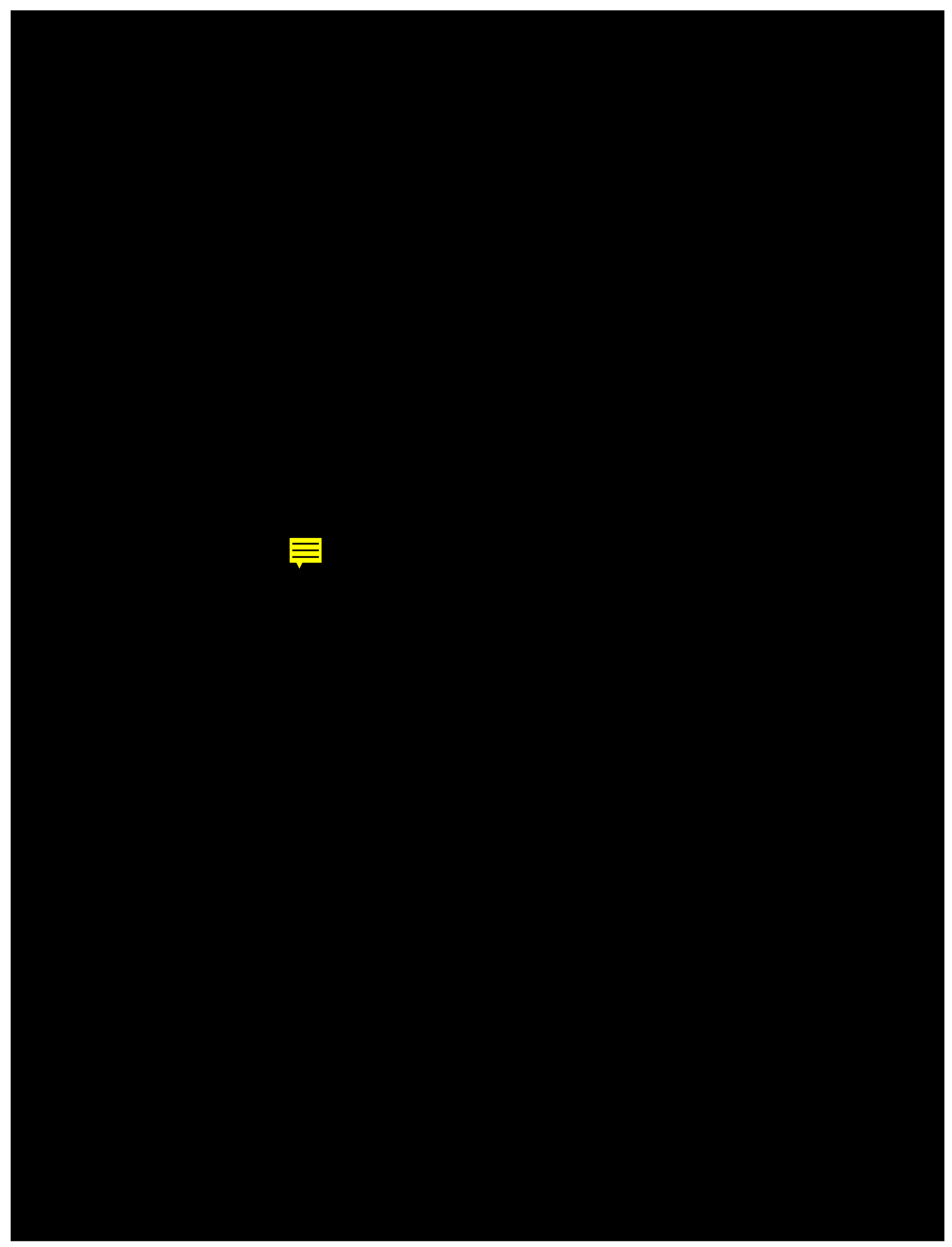


Figure 4. A: Bottom-Stratigraphic section generated by 111 cycles of random glacial advance and retreat and adjusted for Airy isostasy. In each cycle, deposition is 3.5 units $(17.5 \mathrm{~m})$ at grounding line linearly decreasing to 0.5 units $(2.5 \mathrm{~m}) 22$ positions $(220 \mathrm{~km})$ ahead of grounding line. Erosion is decreasing from two units $(10 \mathrm{~m})$ at coast to no erosion at grounding line. Model is presented with large vertical exaggeration $(200: 1)$ to facilitate identification of stratal geometry. TopPositions of grounding line (squares) and shelf edge (red line) in each cycle. Colors of layers correspond to colors of cycles in which they were deposited. U1-U6-Selected unconformities and their corresponding glacial maxima; 1-8-Preserved layers during glacial minima and their corresponding cycles. B: Stratigraphic section generated by model similar to $A$ but with grounding line alternating between coast and shelf edge instead of being randomly located. C: Stratigraphic section generated by model similar to $A$ except that deposition pattern decreases logarithmically (instead of linearly) with distance from grounding line. Tectonic subsidence, initial shelf morphology, and flexure due to load of adjacent ice sheets were incorporated at end of model runs.

the grounding line reaches all available positions.

We assume that during each model ice advance, erosion occurs under the grounded glacier and deposition occurs ahead of the grounding line (Fig. 2). The distributions of erosion and deposition in the models are
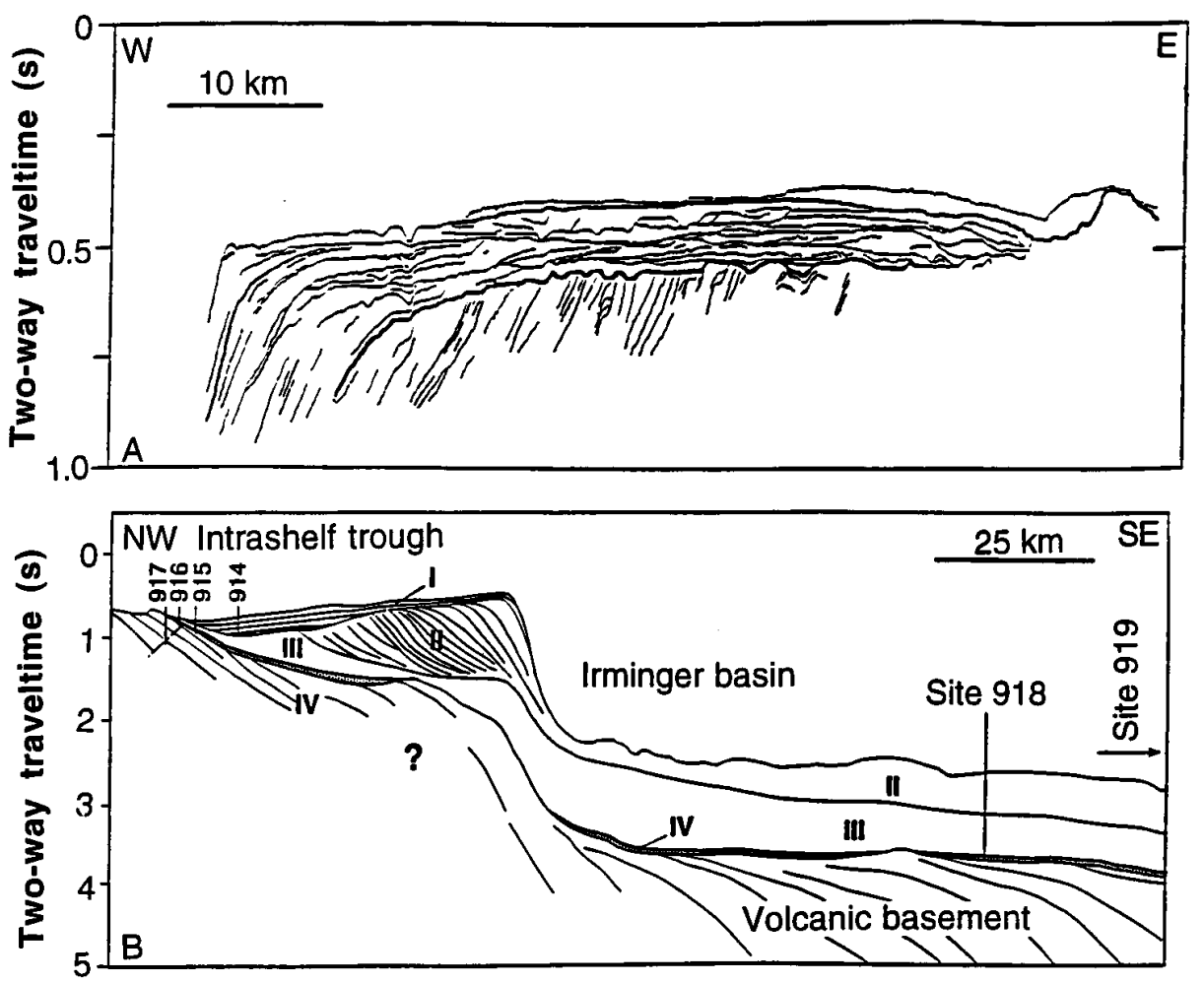

Figure 5. Comparison between glacial sedimentary sections of Barents Sea (top, from Solheim et al., 1991) and South-East Greenland (bottom, from Larsen et al., 1994). Only units I and II contain glacial sediments. 914-918-Locations of Ocean Drilling Program drill holes during Leg 152. grounding line and are independent of the particular position of the grounding line on the shelf. We further assume that the total volume of deposits in each cycle is constant. These assumptions are simple and very general, yet they give rise to a gradual deepening of the inner shelf morphology by erosion and to outer shelf deposition and shelf-edge progradation (Fig. 3).

All sediments that fall in positions beyond the shelf edge fill the first slope position. When this position is filled to the level of the shelf edge at this cycle (after isostatic adjustment), it becomes part of the shelf, and the next position begins to fill (Fig. 2). The model is iteratively adjusted after each cycle for isostasy due to eroded and deposited material. We added moderate "thermal"subsidence for the entire period and the preglacial bathymetry, both of which increase linearly from the coast to the paleoshelf edge, and flexural loading from the adjacent continental ice sheet (from ten Brink and Cooper, 1992). The effect of compaction is ignored, because the porosity of shelf glacial sediments is highly variable with depth (Barron, Larsen, et al., 1989). Compaction of slope sediments could be significant, but the slope stratigraphy is not analyzed here.

We tested the sensitivity of the models to different deposition and erosion patterns. The stratal geometry is insensitive to the

\section{.}

functions only of the distance from the

\section{et} We favor the explanation of smearing and reworking because sediment cores collected in Prydz Bay (Barron, Larsen, et al., 1989) indicate that the sediments are highly reworked, and because South-East Greenland and the Antarctic Peninsula, which exhibit stratal geometries similar to the rest of Antarctica, were probably under subpolar glacial conditions throughout much of their past (Anderson and Ashley, 1991).

The random approach to ice fluctuation is a useful starting point for modeling because there are no independent observations of the extent of grounded ice over geologic time. The random approach assumes that the grounding line often reaches only partway across the shelf. If we assume instead that the location of the grounding line always alternates between the coast and the shelf edge, the model produces a thick inner-shelf sedimentary section that thins toward the outer shelf (Fig. 4B). This has not been observed. Hence, the glacial grounding line presumably occupies different positions on the shelf at different times. 
However, the position of the grounding line across the shelf does not have to be purely random. A bias in the random scheme for the grounding line preferentially to occupy the shelf edge was introduced in the model by increasing the number of positions beyond the shelf edge (Fig. 4A). This bias may address the possibility that as the inner shelf deepens, the grounded glacier is less likely to terminate there than in the shallower outer shelf. Another bias to the random scheme can be introduced by defining the model as a random retreat from the shelf edge rather than random advance and retreat. This model addresses the possibility that much of the shelf deposition occurs during glacial retreat. The stratigraphies produced by these two schemes are not markedly different.

Provided that erosion occurs mainly under the grounded glacier and deposition mainly ahead of the grounding line, the model explains unconformities at the shelf edge and truncation of prograding sequences whenever the grounding line resides for several cycles consistently close to the shelf edge (e.g., U3 in Fig. 4A). Outershelf unconformities and truncations are not very numerous or very periodic in the Antarctic shelves (Fig. 1A; Anderson, 1991; Bartek et al., 1991), which may suggest that the stratigraphic section was generally formed by many rapid fluctuations. The thin sedimentary section of the middle shelf (positions $7-12$ in Fig. 4A) consists of layers deposited during cycles in which the grounding line was close to the coast. However, only partial records of glacial minima ( $\sim 8$ of 25 glacial minima; Fig. 4A) are preserved in the stratigraphic record of the random model; the rest have been subsequently eroded.

\section{DISCUSSION}

Is this model applicable to Northern Hemisphere glaciated shelves? The outer shelf of the Barents Sea has a rugged seaward-dipping morphology and hummocky discontinuous reflections (Fig. 5A). Glaciation on the Barents Shelf started only at 2.5 $\mathrm{Ma}$, the grounding line reached the shelf edge only in the past 0.8 m.y., and the shelf was subject to only a few ice advances (Vorren et al., 1988). The South-East Greenland shelf, in contrast, has a stratal geometry and morphology that are similar to the Antarctic continental shelf (Fig. 5B). Recent Ocean Drilling Program (ODP) drilling on the Greenland margin shows evidence for glaciation dating back to $7 \mathrm{Ma}$ (Larsen et al., 1994). Comparison of these locations suggests that the development of the stratal geometry and reversed morphology of the Antarctic shelves and South-East Greenland probably required many ice fluctua- tions. Johnson et al. (1982) reached a similar conclusion based on the contrasting morphologies of northern and southern polar shelf areas.

We envision that glaciated shelves developed gradually and incrementally over many cycles of glacial advance and retreat (Fig. 3A) until they became "mature." Drilling results from ODP Leg 119 show that the early glacial deposits accumulated in a lacustrine environment, whereas only later deposits accumulated in deep water (Hambrey et al., 1991). The stratigraphy and morphology in the early glacial stages were most likely considerably more affected by eustatic and tectonic changes. However, as the shelf deepened below the range of eustatic changes and acquired its reverse bathymetric profile, these effects became less important. The development of the landward-sloping morphology probably caused water-borne proglacial sediments, deposited during nonglaciated and interglacial periods, to be trapped in the inner shelf. Because the inner shelf is generally the area of greatest erosion (Fig. 3B), these sediments were probably subsequently reworked and transported to the outer shelf and slope regions. Therefore, they are no longer preserved on the shelf in their original form.

\section{CONCLUSIONS}

We suggest that the depositional sequences and sea-floor morphology of the Antarctic shelf exhibit a "mature" glacial geometry that results from time-integrated patterns of glacial erosion and sedimentation relative to the location of the ice grounding line. Eustatic changes, tectonic subsidence, and ice loading have only a secondary effect. We suggest that Northern Hemisphere shelves having morphology and stratigraphy similar to the Antarctic shelf developed during many ice fluctuations and follow the same model.

\section{ACKNOWLEDGMENTS}

Partly supported by National Science Foundation grant OPP-92-20462. We thank J. Anderson, A. Cooper, C. Denham, D. Hutchinson, B. Larsen, and H.-C. Larsen for helpful discussions; J. Zwinakis, R. Drury, and A. Johnson for drafting; and S. Colman, E. Domack, W. Poag, R. Powell, T. Stern, and an anonymous reviewer for thorough reviews.

\section{REFERENCES CITED}

Anderson, J. B., 1991, The Antarctic continental shelf: Results from recent geological and geophysical investigations, in Tingey, R., ed., The geology of Antarctica: Oxford, United Kingdom, Oxford University Press, p. 285-334.

Anderson, J. B., and Ashley, G. M., 1991, Glacial marine sedimentation: Paleoclimatic significance: Geological Society of America Special Paper 261, $225 \mathrm{p}$.

Andrews, J. H., 1987, Late Quaternary marine sediment accumulation in fjord-shelf-deep- sea transacts, Baffin Island to Baffin Bay: Quaternary Science Reviews, v. 6, p. 223-243.

Barron, J., Larsen, B., et al., 1989, Proceedings of the Ocean Drilling Program, Scientific results, Volume 119: College Station, Texas, Ocean Drilling Program, $942 \mathrm{p}$.

Bartek, L. R., Vail, P. R., Anderson, J. B., Emmet, P. A., and Wu, S., 1991, Effect of Cenozoic ice sheet fluctuations in Antarctica on the stratigraphic signature of the Neogene: Journal of Geophysical Research, v. 96, p. $6753-6778$.

Cooper, A. K., Stagg, H., and Geist, E., 1991, Seismic stratigraphy and structure of Prydz Bay, Antarctica: Implications from Leg 119 drilling, in Barron, J., Larsen, B., et al., Proceedings of the Ocean Drilling Program, Scientific results, Volume 119: College Station, Texas, Ocean Drilling Program, p. 5-25.

Domack, E. W., Jull, A. T. J., and Nakao, S., 1991, Advance of East Antarctica outlet glaciers during the Hypsithermal: Implications for the volume state of the Antarctic ice sheet under global warming: Geology, v. 19, p. 1059-1062.

Dowdeswell, J. A., and Scourse, J. D., 1990, Glacimarine environments: Processes and sediments: Geological Society of London Special Publication 53, $423 \mathrm{p}$

Feller, W., 1968, An introduction to probability theory and its applications: New York, John Wiley \& Sons, 509 p.

Hambrey, M. J., Ehrmann, W. U., and Larsen, B., 1991, Cenozoic glacial record of the Prydz Bay continental shelf, in Barron, J., Larsen, B., et al., Proceedings of the Ocean Drilling Program, Scientific results, Volume 119: College Station, Texas, Ocean Drilling Program, p. $77-132$.

Harden, S. L., DeMaster, D. J., and Nittrouer, C. A., 1992, Developing sediment geochronologies for high-latitude continental shelf deposits: A radiochemical approach: Marine Geology, v. 103, p. 69-97.

Johnson, G. L., Vanney, J. R., and Hayes, D. 1982, The Antarctic continental shelf, in Craddock, C., ed., Antarctic geoscience: Madison, University of Wisconsin Press, p. $995-1002$.

Larsen, H. C., Saunders, A. D., Clift, P. D., Beget, J., Wei, W., Spezzaferri, S., and ODP Leg 152 Scientific Party, 1994, Seven million years of glaciation in Greenland: Science, v. 264 , p. 952-955.

Larter, R. D., and Barker, P. F., 1991, Neogene interaction of tectonic and glacial processes at the Pacific margin of the Antarctic Peninsula: International Association of Sedimentologists Special Publication 12, p. 165-186.

Solheim, A., Elverhoi, A., Sletten Andersen, E., and Jahre, H., 1991, Marine geologi$\mathrm{cal} / \mathrm{geophysical}$ cruise on the western Svalbard margin 1990. Cruise report: Norsk Polarinstitutt Raportserie, v. 69, 96 p.

ten Brink, U. S., and Cooper, A. K., 1992, Modeling the bathymetry of the Antarctic continental shelf, in Yoshida, Y., et al., eds., Recent progress in Antarctic earth sciences: Tokyo, Terrapub, p. 763-771.

Vorren, T. O., Hald, M., and Lebesbye, E., 1988 , Late Cenozoic environments in the Barents Sea: Paleoceanography, v. 3, p. 601-612.

Manuscript received November 17, 1994

Revised manuscript received February 3, 1995

Manuscript accepted March 15, 1995 


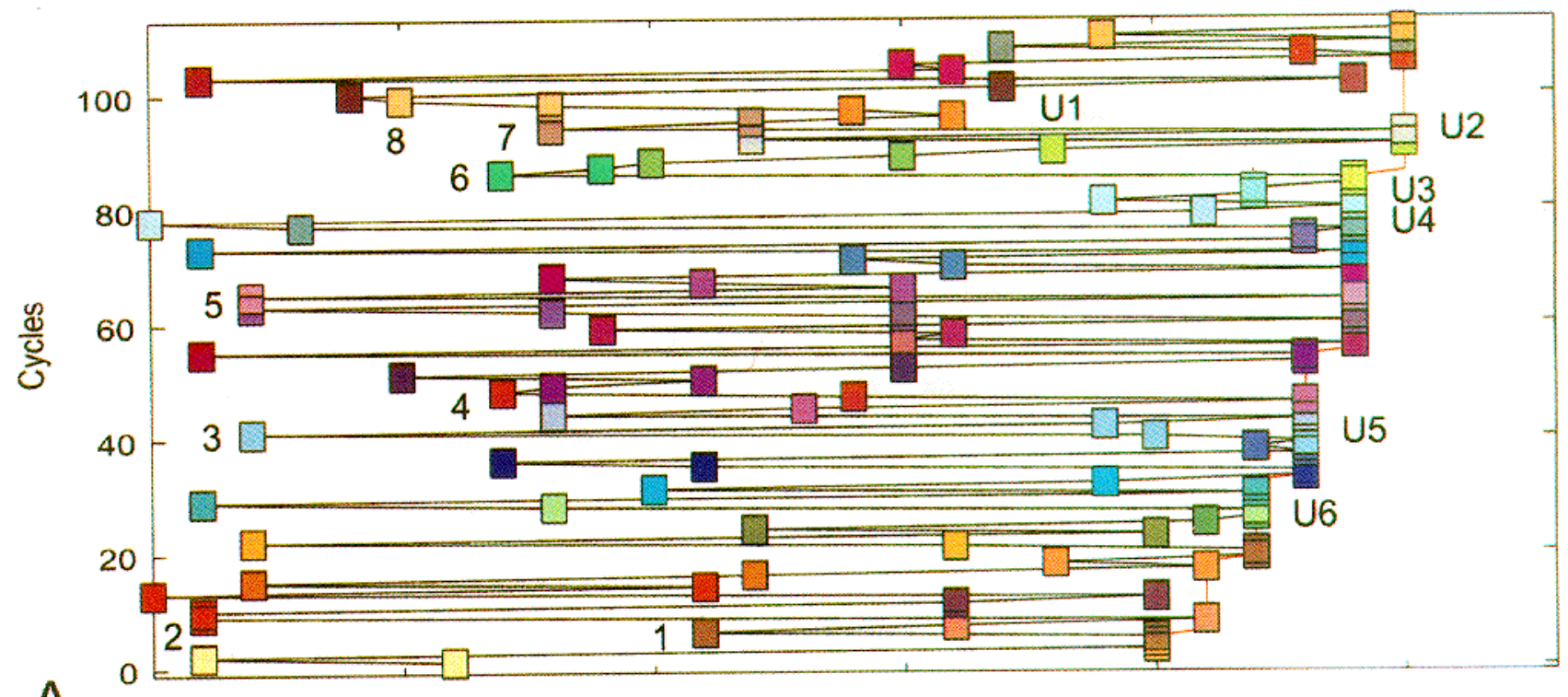

A
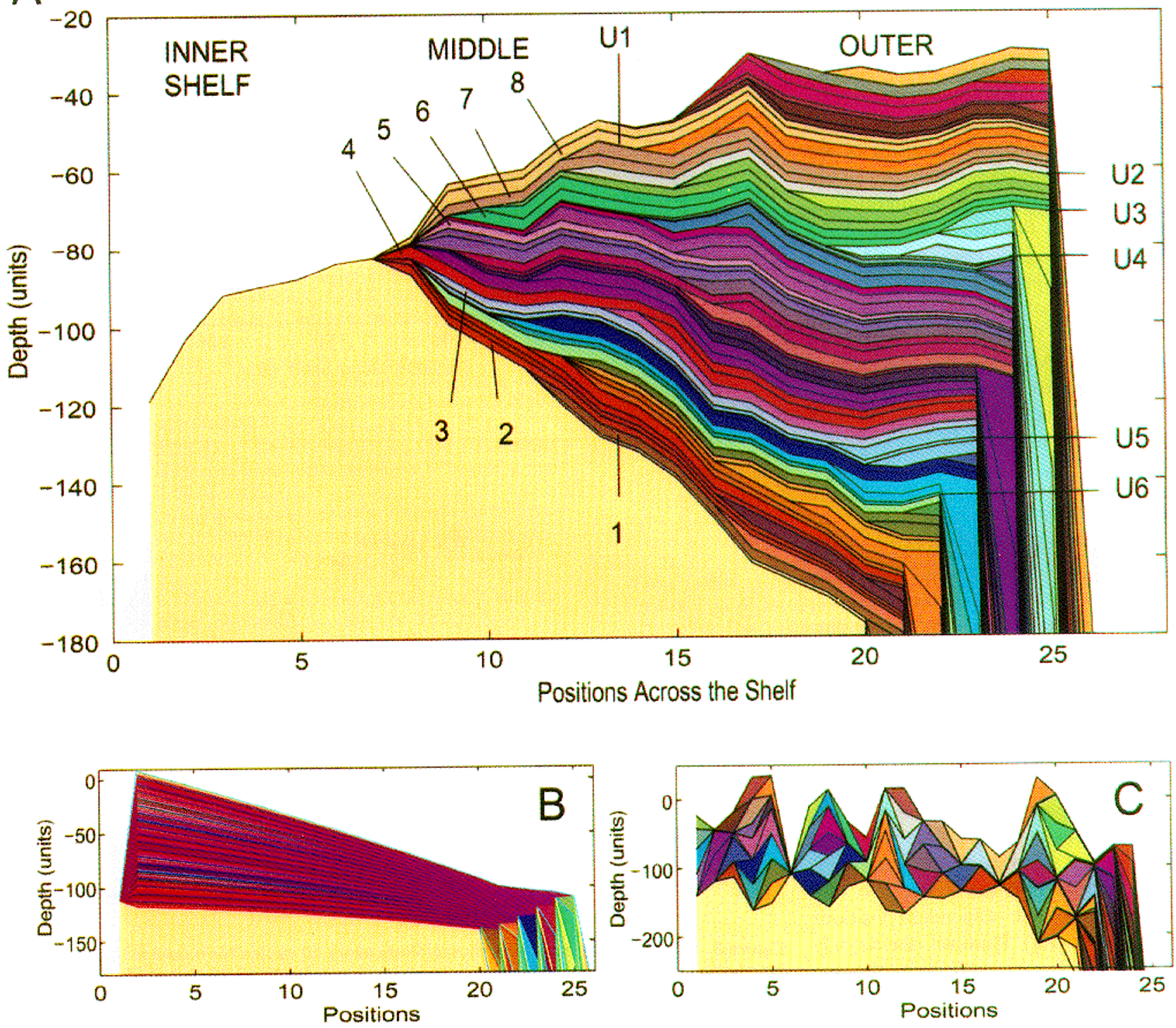